\title{
Aspiration cytology of popliteal lymph nodes as a diagnostic method of canine visceral leishmaniasis (CVL) in areas of socioeconomic vulnerability
}

\section{Citologia aspirativa de linfonodos poplíteos como método diagnóstico de leishmaniose visceral}

canina (LVC) em áreas de vulnerabilidade socioeconômica

Citología por aspiración de ganglios linfáticos poplíteos como método diagnóstico de leishmaniasis visceral canina (LVC) en áreas de vulnerabilidad socioeconómica

\author{
Antônio Carlos Severino Neto \\ ORCID: https://orcid.org/0000-0002-7548-7285 \\ Universidade Federal de Jataí, Brazil \\ E-mail: antonnycarlosnetto@gmail.com \\ Gabriel Lopes Germano \\ ORCID: https://orcid.org/0000-0003-3231-8470 \\ Universidade Federal de Jataí, Brazil \\ E-mail: gabriellopesgermano@gmail.com \\ Thâmara Rossi Martins da Silva \\ ORCID: https://orcid.org/0000-0002-5788-0665 \\ Universidade Federal de Jataí, Brazil \\ E-mail: thamara.rossi@hotmail.com \\ Luiz Antônio de Jesus Sousa \\ ORCID: https://orcid.org/0000-0001-5986-9331 \\ Universidade Federal de Jataí, Brazi \\ E-mail: luizantoniomukies@gmail.com \\ Priscila Gomes de Oliveira \\ ORCID: https://orcid.org/0000-0002-6151-799X \\ Universidade Federal de Jataí, Brazil \\ E-mail: vetpriscilagomes@gmail.com \\ Reiner Silveira de Moraes \\ ORCID: https://orcid.org/0000-0002-1468-2968 \\ Universidade Federal de Jataí, Brazil \\ E-mail: rmoraes@ualberta.ca \\ Dirceu Guilherme de Sousa Ramos \\ ORCID: https://orcid.org/0000-0001-9603-6638 \\ Universidade Federal de Jataí, Brazil \\ E-mail: dgramos_vet@hotmail.com
}

\begin{abstract}
Leishmaniasis is an endemic disease in Goiás and has high lethality owing to its high zoonotic potential. In dogs, the disease manifests based on the parasitic load, with clinical presentation as the starting for diagnosis. Diagnostic methods are used to confirm the disease, with emphasis on lymph node aspiration cytology, which is a high-standard technique owing to its low cost, ease of performance, and high specificity. The aim of this study was to demonstrate aspiration lymph node cytology as a diagnostic method for canine visceral leishmaniasis (CVL) in areas containing low-income populations with poor access to molecular tests. Three dogs with suspected CVL were studied at Veterinary Hospital of the Federal University of Jataí, in which popliteal lymph node cytology was performed, owing to easy access, and screening and confirmatory examinations were undertaken by the Central Public Health Laboratory. The results showed three positive animals in the cytology and only one positive in the other tests; therefore, there was the possibility of the occurrence of false negatives in serological tests given the time required for seroconversion. Thus, cytology is an important diagnostic technique in areas where molecular tests are not available.
\end{abstract}

Keywords: Amastigotes; Leishmania spp; Macrophages; Onychogryphosis.

\section{Resumo}

A leishmaniose é uma doença endêmica em Goiás e apresenta alta letalidade devido ao seu alto potencial zoonótico. Em cães, a doença se manifesta baseada na carga parasitária, com apresentação clínica como princípio para o diagnóstico. Métodos de diagnóstico são utilizados para confirmar a doença, com ênfase na citologia de aspiração de linfonodos, que é uma técnica de alto padrão devido ao seu baixo custo, facilidade de desempenho e alta especificidade. O objetivo deste estudo foi demonstrar a citologia de aspiração de linfonodos como um método diagnóstico para 
leishmaniose visceral canina (LVC) em áreas contendo populações de baixa renda com pouco acesso a testes moleculares. Três cães com suspeita de LVC foram estudados no Hospital Veterinário da Universidade Federal de Jataí, no qual foi realizada citologia de aspiração de linfonodo poplíteo, devido ao fácil acesso, e exames de triagem e confirmação foram realizados pelo Laboratório Central de Saúde Pública. Os resultados mostraram três animais positivos na citologia e apenas um positivo nos outros testes, demonstrando a possibilidade de ocorrência de falsos negativos em testes sorológicos, dado o tempo necessário para soroconversão. Assim, a citologia é uma importante técnica de diagnóstico em áreas onde os testes moleculares não estão disponíveis.

Palavras-chave: Amastigotas; Leishmania spp; Macrófagos; Onicogrifose.

\section{Resumen}

La leishmaniasis es una enfermedad endémica en Goiás y tiene una alta letalidad debido a su alto potencial zoonótico. En los perros, la enfermedad se manifiesta en función de la carga parasitaria, con la presentación clínica como principio de diagnóstico. Se utilizan métodos de diagnóstico para confirmar la enfermedad, con énfasis en la citología por aspiración de ganglios linfáticos, que es una técnica de alto estándar debido a su bajo costo, facilidad de realización y alta especificidad. El objetivo de este estudio fue demostrar la citología por aspiración de ganglios linfáticos como método de diagnóstico para la leishmaniasis visceral canina (CVL) en áreas que contienen poblaciones de bajos ingresos con poco acceso a pruebas moleculares. Se estudiaron tres perros con sospecha de LVC en el Hospital Veterinario de la Universidad Federal de Jataí, en el que se realizó citología por aspiración de ganglio linfático poplíteo, por su fácil acceso, y se realizaron pruebas de cribado y confirmación por parte del Laboratorio Central de Salud Pública. Los resultados arrojaron tres animales positivos en la citología y solo uno positivo en las demás pruebas, lo que demuestra la posibilidad de la ocurrencia de falsos negativos en las pruebas serológicas, dado el tiempo necesario para la seroconversión. Por lo tanto, la citología es una técnica de diagnóstico importante en áreas donde las pruebas moleculares no están disponibles.

Palabras clave: Amastigotes; Leishmania spp; Macrófagos; Onicogrifosis.

\section{Introduction}

Leishmaniasis is a disease with zoonotic potential, which is caused by an obligatory intracellular protozoan belonging to the genus Leishmania (Limeira et al., 2019). The existence of more than 20 species of Leishmania that cause the disease is recognized by the World Health Organization (WHO, 2017), which present clinical and epidemiological differences depending on the Leishmania species involved (Benassi et al., 2018).

Owing to its clinical complexity, leishmaniasis is viewed as a serious public health problem and is the most important emerging disease in Latin America (Barros et al., 2019), especially in countries that have tropical and subtropical climates (Benassi et al., 2018). According to Andrade-Filho et al. (2017), Brazil is a country with a high incidence of visceral leishmaniasis (VL) and in the Northeast, Southeast, and Midwest regions the disease is endemic (Escobar et al., 2019).

The state of Goiás, located in the central-western region of Brazil, is endemic for the disease, with reported cases of human VL (HVL) and canine VL (CVL) in several municipalities (Goiás, 2017). The lethality rate of the disease in the state is high and between 2007 and 2015, out of 304 positive cases, there were 34 deaths, a lethality rate of approximately $11 \%$. However, in 2018 , the lethality rate was approximately $7.5 \%$ out of 53 cases diagnosed as positive (Goiás, 2019).

Leishmania infantum (L. infantum) is the species that causes CVL and dogs are the domestic reservoir (Limeira et al., 2019). The main transmission path of the etiological agent is by inoculation via the hematophagy of mosquitoes (Phlebotominae) of the genus Lutzomyia (Silva et al., 2019), with Lutzomyia longipalpis being the main sandfly involved in the transmission of Leishmania spp. (Dias et al., 2019).

The transmission alternates between vertebrate and invertebrate hosts. The biological cycle begins when the vector performs blood feeding on an infected vertebrate host, ingesting the amastigote forms of Leishmania spp. present in the bloodstream. After a new blood feeding in a healthy animal, the promastigote form is differentiated into amastigote and may also rupture the macrophage, again being phagocyted and spreading through tissues such as the spleen, liver, lymph nodes, and bone marrow (Ribeiro et al., 2018; Silva et al., 2018).

The clinical signs of leishmaniasis in dogs vary according to the parasitic load of the individual, including skin changes such as nasal and cushion hyperkeratosis, alopecia, desquamation, anorexia, and onychogryphosis, and ophthalmic changes such 
as uveitis and conjunctivitis (Torrecilha et al., 2016; Abbiati et al., 2019). Based on the clinical changes and knowledge of the disease, a diagnosis can be obtained, which can be undertaken using lymph node aspiration cytology, a high-standard diagnostic tool (Noli \& Saridomichelakis, 2014).

According to Ramos et al. (2013), L. infantum has a tropism for lymphoid organs, which makes them important in detecting the protozoan. Thus, cytology can be used as a diagnostic method for CVL because amastigote forms of Leishmania can be found in infected organs and tissues, among which are the bone marrow, lymph nodes, peripheral skin, and blood (Maia \& Campino, 2008). Therefore, given the zoonotic importance of the disease and the local social aspect, the present study aimed to demonstrate lymph node aspiration cytology as a diagnostic method for CVL in low-income population regions as the city focus of the study, as well as in regions where access to molecular techniques is scarce or nonexistent.

\section{Methodology}

Three dogs with differential diagnosis of CVL, aged between 3 and 9 years old of both genders, from the Veterinary Medical Care at the Veterinary Hospital of the Federal University of Jataí (UFJ) were included in the study. The selection criteria were based on the presence of suggestive clinical signs that led to the differential diagnosis of VL. Common clinical signs include lymphadenopathy, emaciation, polyuria, polydipsia, vomiting, neuralgia, polyarthritis, polymyositis, fever, and splenomegaly (Tilley \& Smith Jr., 2008). For this study, the clinical presentation seen in the patients suspected for the disease is shown in Figure 1. Another considered criterion was the animals belonging to regions known as being endemic for the disease.

Figure 1. Characteristic clinical signs observed in the animals (1,2 and 3) of this study that led veterinarians to the suspicious diagnosis of Leishmaniasis and so conducted them to aspirative cytology in the aforementioned teaching hospital in Jataí, Goiás. Onychogryphosis (A); Pigmentation and pustule rupture areas (B); Ophthalmic alterations (C); Flaky skin (D).

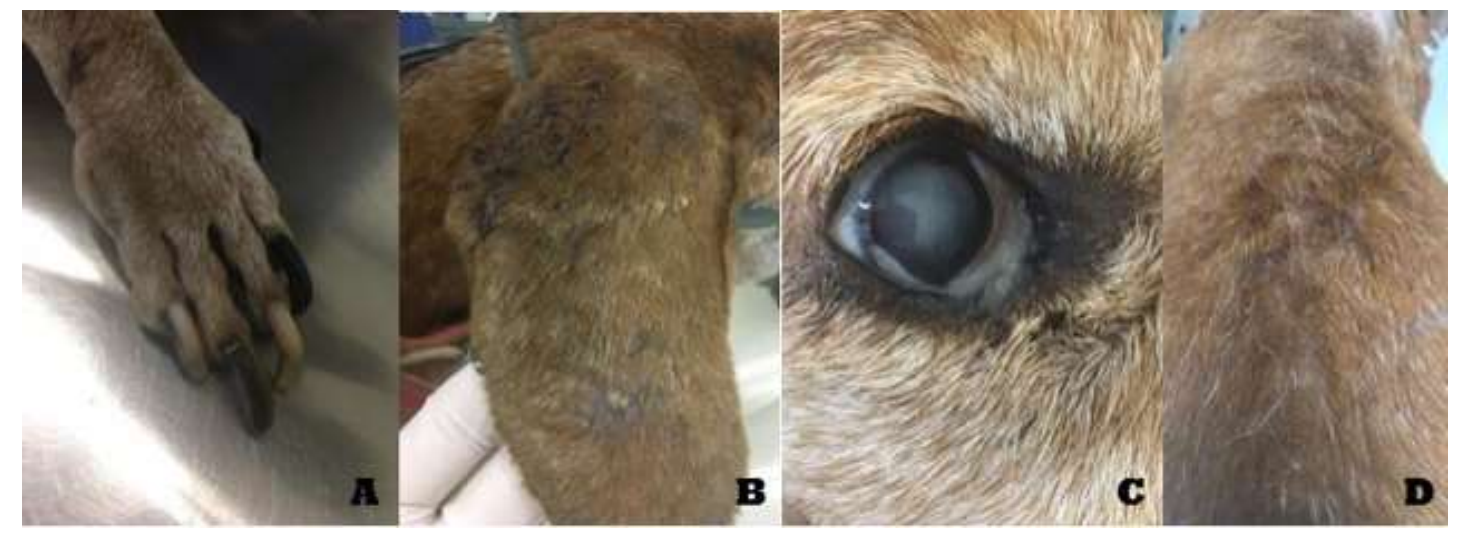

Source: Author's collection.

The lymph nodes of choice in the present study had lymphadenomegaly and allowed better access for the collection of the required material. Fine needle aspiration puncture technique of the popliteal lymph nodes was performed and the samples were sent for cytological analysis. This technique was adopted as a definitive diagnostic method in the present study because it is a method available at the teaching hospital, is inexpensive (considering the low income of the target public), and molecular techniques were unavailable at the university and surrounding cities.

After collection, the material was deposited on glass slides for microscopy and the overlapping content was smeared. Then, the slides were sent to the Laboratory of Pathology and Veterinary Parasitology at the UFJ, where they were stained with a staining kit following the technique described according to the manufacturer's instructions (Laborclin ${ }^{\circledR}$ ). Analysis of the slides was performed using an optical microscope with a 1000x magnification lens, looking for amastigote forms of the parasite. When 
positive in cytology, the cases were sent to the Zoonosis Surveillance Unit in the municipality of Jatai together with the Central Public Health Laboratory (LACEN-GO) to perform the chromatographic (TR-DPP) and immunoenzymatic (ELISA) tests.

\section{Results}

\section{Animal 1}

Male canine, Teckel breed, rescued from the municipality of Jataí, Goiás, and with no clinical history. On physical examination, clinical signs such as cachexia and severe dehydration were found, in addition to those consistent with CVL including bilateral lymphadenomegaly of the popliteus, hyperpigmented areas in the ventral region, flaky skin throughout the dorsal region of the body and head, multifocal alopecia, pustules, onychogryphosis, and uveitis. Serology (SNAP Leishmania IDEXX test) was performed for CVL, with the animal being the reagent, and cytology of the right and left popliteal lymph nodes, where amastigote forms of Leishmania spp. were distributed throughout the macrophage cytoplasm and extracellular amastigotes were found close to the lymphocytic cells in both lymph nodes (Figure 2).

Figure 2. Cytology of the left popliteal lymph node showing the amastigote forms of Leishmania spp. in macrophage cytoplasm (circle) and the extracellular amastigote forms of Leishmania spp. (arrows).

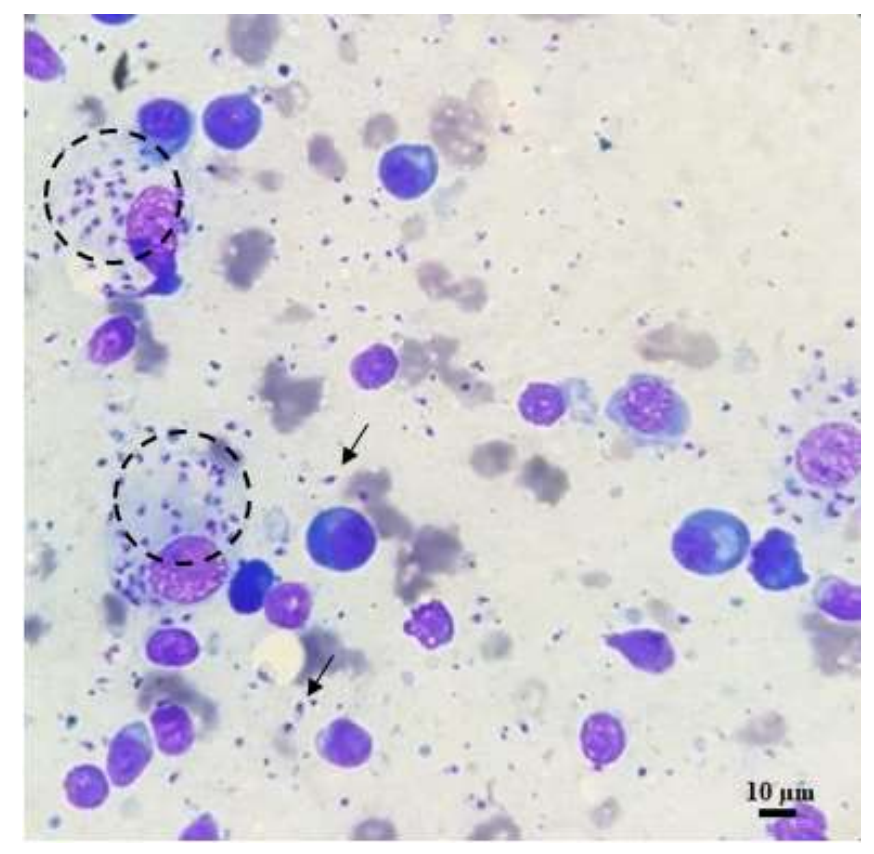

Source: Author's collection.

\section{Animal 2}

Male canine, Cane Corso breed, 3 years old, with a history of parents from Uberlândia, Minas Gerais, which is an endemic area for leishmaniasis. During the inspection, flaky skin on the dorsal region of the body and dekeratinization in the cushions of the thoracic and pelvic members were found, which were more evident in the pelvic members. On palpation, bilateral popliteal lymphadenomegaly was found; however, this was milder than that presented by animal 1. Serology for CVL (Test SNAP Leishmania - ALERE) and cytology of the right and left popliteal lymph nodes were performed. The animal tested nonreactive in the serological examination and positive for Leishmania spp. in the cytological examination of both lymph nodes, in which amastigote forms were found distributed in the macrophage cytoplasm (Figure 3). 
Figure 3. Cytology of the right popliteal lymph node showing amastigote forms of Leishmania spp. in the macrophage cytoplasm.

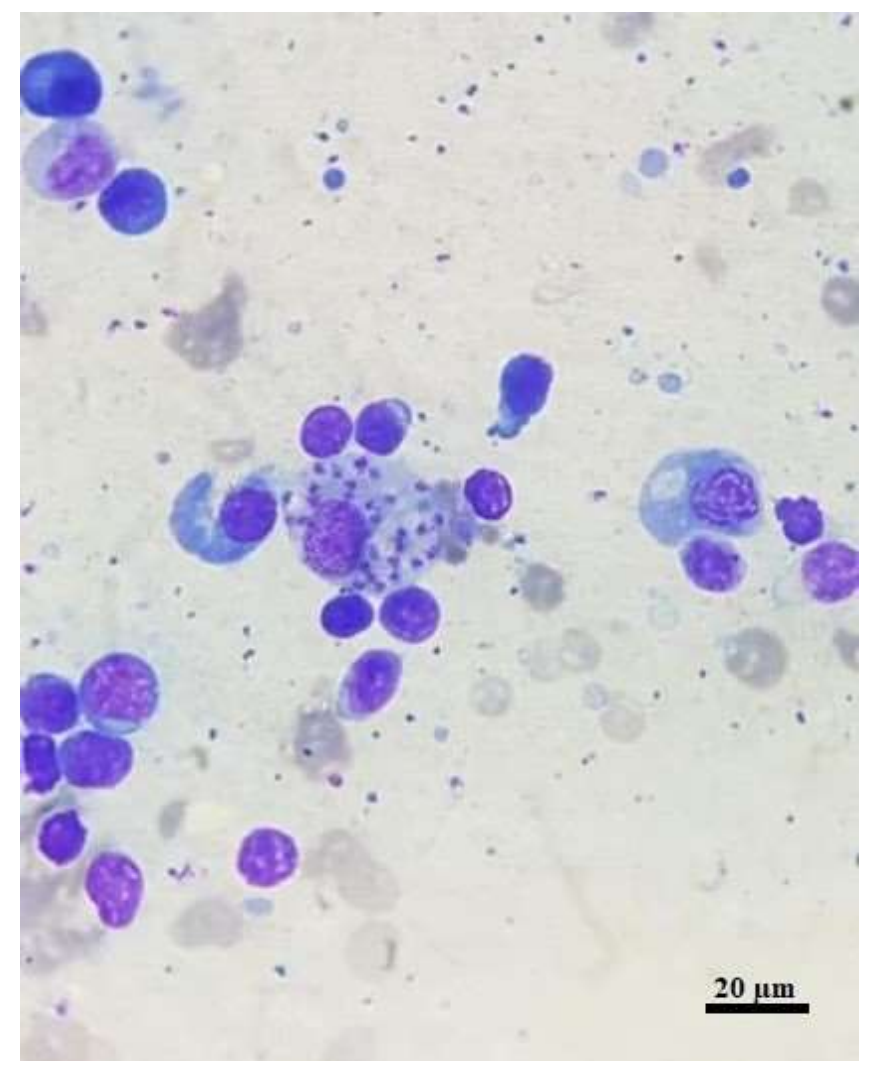

Source: Author's collection.

\section{Animal 3}

Female canine, Pinscher breed, from São Simão, Goiás, with a history of receiving treatment for hemoparasitosis three times and showing no improvement, and originating from another municipality in the state of Goiás and having contact with other animals with similar clinical signs. After physical examination, signs of progressive weight loss, dry seborrhea, onychogryphosis, onychogryphosis, a lesion on the muzzle, and alopecic areas distributed throughout the body, mainly the tail, were identified. The serological examination was not performed in a hospital setting owing to the tutor's inability to obtain the required funds. Cytology was performed and a positive result for Leishmania spp. was obtained and there was intense parasitism in the right and left popliteal lymph nodes, with a marked presence of amastigote forms in the macrophage cytoplasm, and a wide distribution in the glass slide seen in the extracellular areas (Figure 4). 
Figure 4. Cytology of the right popliteal lymph node showing the amastigote forms of Leishmania spp. in the macrophage cytoplasm (circles) and the extracellular amastigote forms of Leishmania spp. (arrows).

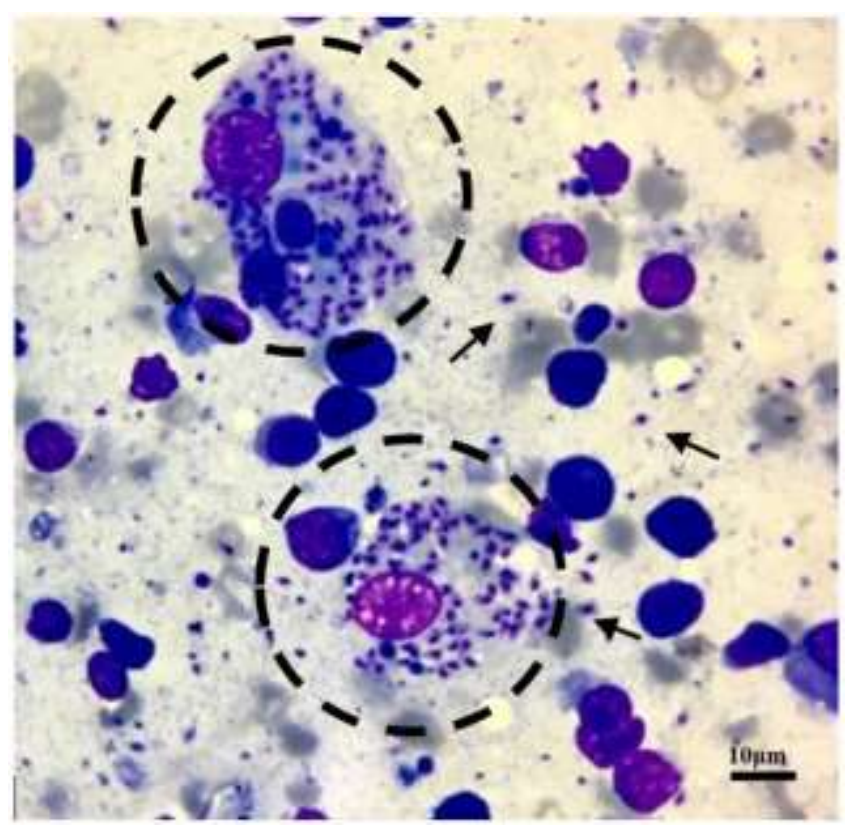

Source: Author's collection.

After testing positive for lymph node cytology, the cases were sent to the Zoonosis Surveillance Unit in the municipality of Jataí, where the animals were tested together with the LACEN-GO using serological screening (TR-DPP: chromatographic immunoassay) and confirmatory tests (ELISA: enzyme immunoassay). The results from the serological tests of the animals in the present study are shown in Table 1.

Table 1. Results for the screening (TR-DPP) and confirmatory (ELISA) tests performed by the LACEN-GO for three animals suspected of having CVL in Jataí, Goiás, with positive lymph node cytology. Jataí, Goiás, 2020.

\begin{tabular}{lcc}
\hline & TR-DPP & ELISA \\
\hline ANIMAL 1 & Inconclusive & Non-reagent \\
ANIMAL 2 & Non-reagent & Non-reagent \\
ANIMAL 3 & Reagent & Reagent \\
\hline
\end{tabular}

Source: Author's collection.

\section{Discussion}

VL is an endemic zoonosis in several countries including Brazil, a country in which the increasing number of cases in the past decades has been mainly related to urbanization (Conti et al., 2016). Located in a region as being endemic for VL, the state of Goiás, Escobar et al. (2019) in a retrospective study in 2018 analyzed 152 HVL forms, of which 40.5\% were positive, with this being the occurrence distributed in several municipalities in the state, with a lethality rate of approximately $7.5 \%$ (Goiás, 2019).

Regarding CVL, the same retrospective study from 2018 also analyzed approximately 1176 dog files, where $62.8 \%$ were positive, $36.1 \%$ were negative, and $1.2 \%$ were undetermined (Goiás, 2019). In a study by Azevedo et al. (2011), in the municipality of Goiânia, among 214 dogs investigated for indirect immunofluorescence reaction test, 9,3\% were positive and $90,6 \%$ negative, meanwhile in skin and lymph node parasitological tests, $2,8 \%$ were positive and 97,2\% negative. Yet, according 
to these researchers, positive animals in both tests were symptomatic in their majority, and this corroborates with our study in which animals presented clinical signs compatible with those in animals with CVL.

In contrast to the clinical signs seen in the physical examination of animals 1 and 3, VL was a clinical suspicion because onychogryphosis, desquamation, and lymphadenopathy are characteristic clinical manifestations of the disease (Abbiati et al., 2019). However, animal 2 only presented bilateral lymphadenopathy of the popliteus and a history of parents from Uberlândia, Minas Gerais, an endemic area for leishmaniasis according to the Epidemiological Bulletin 2010-2015, which allowed the diagnosis of the Leishmania spp. infection (Minas Gerais, 2016).

This variety in the intensity of clinical signs demonstrated by the animals in the present study might be correlated with the intensity of parasitism (parasitic load). Animals 1 and 3 had more pronounced parasitism than that of animal 2 as seen in the cytological images, what can be seen by the extension of amastigote forms beyond the intracellular limit. This scenario was in agreeance with Torrecilha et al. (2016) who revealed the existence of a positive correlation between the intensity of clinical signs and parasitic load.

The diagnosis of CVL can be performed using serological tests such as the rapid screening test (TR - DPP) and immunoenzymatic assay (ELISA), which are the most commonly used methods. Molecular tests such as polymerase chain reaction and parasitological tests such as aspiration cytology of lymph nodes and bone marrow can also be used for the diagnosis of the disease (Lopes et al., 2017). Although cytology is given as an invasive method, with the right asepsis, technique and qualified professionals, it can be performed by veterinarians as done in this study.

Regarding the serological tests, ELISA has a sensitivity and specificity calculated at $100 \%$ and $93 \%$, respectively, whereas TR - DPP is 93\% and 92\%, respectively, for L. infantum (Silva et al., 2013). When submitted to the aforementioned tests, animals 1 and 2 were inconclusive and non-reagent to TR - DPP, respectively, and both were non-reactive to the ELISA test, whereas animal 3 was reagent for both tests. These tests detect and quantify the presence of antibodies in the organism; therefore, an infected animal without having undergone seroconversion might not be reagent in the tests, which is believed to explain the results obtained for animals 1 and 2. In contrast, animal 3 showed positive result in both tests as demonstrated in table 1, plus cytology. This last is thought to be due to its more defined history, longer time of clinical presentation and lack of diagnostic what led the animal clinical signs worsening and only later on the diagnose was stablished.

Considering the relevance of the Zoonosis Surveillance Unit and the performance of screening tests as TR - DPP, it is important to reveal that when compared to large cities, municipalities distant from urban centers most of the time do not have a unit as the mentioned one to assist and give support to local veterinarians in need of its services. Also, the ELISA test is not always performed, but the retest of the screening test. In the municipality of this study, the local unit performed the screening test and after that sent material to LACEN-GO for both TR - DPP and ELISA. Therefore, this reality is not present in all municipalities.

Most dogs develop an immune response as soon as the organism has its first contact with the parasite, others do not, which is dependent on the time of the antibody production variable and the immune system of each animal. The seroconversion time estimated in natural conditions is from 1 to 22 months and in experimental conditions is from 1 to 6 months, which allows for the occurrence of false negatives if the serological test is performed before seroconversion has occurred (Paltrinieri et al., 2010).

The possibility of false negatives appearing in serological tests of animals infected with Leishmania spp. reaffirms the need to use aspiration cytology as a tool to aid diagnosis because it has high sensitivity and specificity, allowing the visualization of the etiological agent itself (Saridomichelakis et al., 2005). It is understandable that this technique does not provide differentiation of Leishmania species in the material, therefore it is a technique that is easy to perform and is inexpensive. In 
addition, cytology is more accessible to tutors who have low purchasing power and is a tool for areas where molecular and serological diagnoses are not fully available (Oliveira et al., 2011).

According to Ramos et al. (2013), Leishmania spp. has a tropism for lymphoid organs and the lymph nodes are the source of the best samples owing to the ease of access, thus justifying the collection of samples from the reactive popliteal lymph nodes in the present study. Some studies have demonstrated the applicability of cytology as a tool for diagnostic. In his study, Teles et al. (2012) conducted a parasitological investigation in in which smears from popliteal lymph nodes of dogs with at least one amastigote form were positive for VL. Similarly, the identification of amastigote forms for the diagnosis of VL from smear lymph nodes was performed in humans and primates (Pal \& Biswas, 2018; Santos \& Oliveira, 2019).

By considering cytology as a high-standard diagnostic tool because of its low cost, minimal technological requirements, rapid availability of results, and absolute specificity (Noli \& Saridomichelakis, 2014), in this study, lymph node aspiration cytology showed the presence of amastigote forms in the macrophage cytoplasm of all the animals, which allowed the confirmation of the diagnosis of CVL. Animals 1 and 3, in addition to intracellular forms, presented extracellular amastigotes, which can be explained by the infected cells being damaged during the preparation of the blood smear, rupturing the macrophage membrane, and thus the parasites are found on the outside of the macrophages (Paltrinieri et al., 2016).

In contrast, Liu and Uzonna (2012) explained that after internalization in the macrophages, the promastigote forms start to differentiate into amastigote forms, which are divided several times by binary fission, thus breaking the macrophages and infecting the surrounding macrophages. Therefore, this is the explanation for the extracellular amastigote forms found in the animals in the present study, which also explains the more pronounced parasitism and consequent clinical signs in animals who had extracellular forms. Considering that the animals in the present study were attended in a teaching hospital, under the care of tutors who had low purchasing power to pay for higher-value tests and treatment and also the lack of molecular tests within a radius of $300 \mathrm{~km}$, cytology is useful for analysis in such cases owing to its advantages mentioned previously. In addition, the method indicated the presence of the causal agent itself, i.e., an infected animal. It is clearly understandable that the number of animals in this study was low, however, the relevance of considering aspiration cytology as an isolated method to diagnose and treat CVL in areas where other tests are not available, make this study applicable and of interest in interior municipalities.

\section{Conclusion}

In regions of socioeconomic vulnerability and poor access to molecular techniques, the aspiration cytology of lymph nodes is useful to diagnose animals infected by Leishmania spp. Cytology as a diagnostic method presents high sensitivity and specificity once it identifies the etiologic agent of the disease, characterizing the animal as infected. Molecular techniques are excellent for diagnosing animals with CVL; however, considering the time required for seroconversion to identify positive animals using such techniques, the application of the cytological technique is of great importance for the diagnosis of CVL, especially for patients in vulnerable environments, and so that control measures and treatment can be administered when applicable. The performance of epidemiological studies with larger sample sizes and the comparison between the sensitivity and specificity of serological and parasitological tests with the polymerase chain reaction (PCR) test comprise perspectives for future studies on CVL. Hence, for this to be possible, an expansion of access to PCR in meso and microregions is needed, especially in areas of socioeconomic vulnerability, what will then allow a quick and accurate diagnosis and so, the implementation of control measures for the disease.

\section{References}

Abbiati, T. C., Freitas, D. M., Alves, L. C., Freitas, B. G., Rezende, R. S., Barbosa, S. G., Teixeira, A. L., Jorge, A., Santos, S. M. \& Lopes M. C. (2019) Leishmaniose visceral canina: Relato de caso. PUBVET Medicina Veterinária,13(34), 1-8. 
Andrade-Filho, J. D., Scholte, R. G. C., Amaral, A. L. G., Shimabukuro, P. H. F., Carvalho, O. S. \& Caldeira, R. (2017). Occurrence and probability maps of lutzomyia longipalpis and lutzomyia cruzi (díptera: psychodidae: phlebotominae) in brazil. Journal of Medical Entomology, 54(5): 1430-1434.

Azevedo, E. M. R., Duarte, S. C., Costa, H. X., Alves, C. E. F., Neto, O. J. S., Jayme, V. S. \& Linhares, G. F. C. (2011) Estudo da leishmaniose visceral canina no município de Goiânia, Goiás, Brasil. Revista de Patologia Tropical,40(2).

Barros, A. L. C., Benites, A. P., Mateus, N. L. F. \& Fernandes, C.E. (2019). Histopathological alterations in the reproductive tract of male dogs with canine visceral leishmaniasis. Semina: ciências agrárias, 40(2), 665-676.

Benassi, J. C., Benvenga, G. U., Ferreira, H. L., Soares, R. M., Silva, D. T., Pereira, V. F., Ruiz, V. L. A. \& Oliveira, T. M. F. S. (2018). Molecular and serological detection of leishmania spp. in horses from an endemic área for canine visceral leishmaniasis in southeastern brazil. Pesquisa Brasileira Veterinária, 38(6), 1058-1063.

Conti, R., Lane, V. M., Montebello, L. \& Junior, V. P. (2016). Visceral leishmaniasis epidemiologic evolution in timeframes, based on demographic chages and scientific achievements in Brazil. Jornal of Vector Borne Diseases, 53(2), 99-104.

Dias, R. C. F., Pasquali, A. K. S., Thomaz-Soccol, V., Pozzolo, E. M., Chiyo, L., Alban, S. M., Fendrich, R. C., Almeida, R. A. A., Ferreira, F. P., Caldart, E. T., Freire, R. L., Mitsuka-Braganó, R. \& Júnior, A. B. (2019). Autochthonous canine visceral leishmaniasis cases occur in paraná state since 2012: isolation and identification of Leishmania infantum. Brazilian Journal of Veterinary Parasitology, 29(1).

Escobar, T. A., Dowich, G., Cantele, L.C., Zuravski, L., Ferrareze, P. A. G., Duarte, C. A., Silva, L. K. R., Lübeck, I. \& Manfredini, V. (2019). Molecular detection of leishmania spp. in Brazilian cross-border south region mammalian hosts. Transboundary and Emerging Diseases, 67(2), 476-480.

Goiás, 2017. Marques, S. F. F, Jesus, A. K. \& Sousa, F. A. Leishmaniose Visceral em Goiás - Aspectos epidemiológicos. Boletim Epidemiológico [online]. 2017 http://www.sgc.goias.gov.br/upload/arquivos/2017-10/leishmaniose-visceral-em-goias---aspectos-epidemiologicos.pdf.

Goiás, 2019. Reis L. A. L., Marques S. F. F. Leishmaniose visceral em Goiás o ano de 2018. Boletim Epidemiológico. https://www.saude.go.gov.br/images/imagens_migradas/upload/arquivos/2019-10/boletim-epidemiologico---leishmaniose-visceral-em-goias-no-ano-de-20181.pdf.

Limeira, C. H., Alves, C. J., Azevedo, S. S., Santos, C. S. A. B., Melo, M. A., Soares, R. R., Barnabé, N. N. C. \& Rodrigues, G. Q. (2019). Clinical aspects and diagnosis of leishmaniasis in equids: a systematic review and meta-analysis. Brazilian Journal of Veterinary Parasitology, 28(4), 574-581.

Liu, D. \& Uzonna, J. E. (2012). The early interaction of Leishmania with macrophages and dendritic cells and its influence on the host immune response. Frontiers in Cellular and Infection Microbiology, 2(83), 1-8.

Lopes, E. G., Sevá, A. P., Ferreira, F., Nunes, C. M., Keid, L. B., Hiramoto, R. M., Ferreira, H. L., Oliveira, M. F. S., Bigotto, M. F. D., Galvis-Ovallos, F., Galati, E. A. B. \& Soares, R. M. (2017). Serological and molecular dianostic tests for canine visceral leishmaniasis in Brazilian endemic área: one out of live seronegative dogs are infected. Epidemiology and Infection, 145 (12), 2436-2644.

Maia, C. \& Campino, L. (2008). Methods for disgnosis of canine leishmaniasis and immune response to infection. Veterinary Parasitology, 158(4), $274-287$.

Noli, C. \& Saridomichelakis, M. N. (2014). An update on the diagnosis and treatment of canine leishmaniosis caused by Leishmania infantum (syn. 1. chagasi). Veterinary Journal ,202(3), 425-435.

Oliveira, T. S., Miranda, F. G., Ribeiro, V. M. \& Santos, R. L. (2011). Análise de métodos diagnósticos para leishmaniose visceral canina a partir de um levantamento de casos atendidos em uma clínica veterinária na cidade de Belo Horizonte, MG. Medvep - Revista Cientifica de Medicina Veterinária - Pequenos Animais e Animais de Estimação, 9(31): 692- 696.

OMS - ORGANIZAÇÃO MUNDIAL DA SAÚDE. Global leishmaniasis update, 2006-2015: a turning point in leishmaniasis surveillance. 2017 http://apps.who.int/iris/bitstream/10665/258973/1/ WER9238.pdf? Ua = 1.

Pal, S. \& Biswas, B. (2018). Fine-needle aspiration cytology of leishmanial lymphadenitis in an HIV-reactive patient: Report of a rare case. Tropical Parasitology, 8(1), 50-52.

Paltrinieri, S., Gradoni, L., Roura, X., Zatelli, A. \& Zini, E. (2016). Laboratory tests for diagnosing and monitoring canine leishmaniasis. Veterinary Clinical Pathology, 45(4), 552-578.

Paltrinieri, S., Solano-Gallego, L., Fondati, A., Lubas, G., Gradoni, L., Castagnaro, M., Crotti, A., Maroli, M., Oliva, G., Roura, X., Zatelli, A. \& Zini, E. (2010). Guidelines for diagnosis and clinical classification of leishmaniasis in dogs. Journal of the American Veterinary Medical Association, 236(11), $1184-1191$.

Ramos, R. A. N., Ramos, C. A. N., Santos, E. M. S., Araújo, F. R., Carvalho, G. A., Faustino, M. A. G. \& Alves, L. C. (2013). Quantification of Leishmania infantum DNA in the bone marrow, lymph node and spleen of dogs. Brazilian Journal of Veterinay Parasitology, 22(3), 346-350.

Ribeiro, R. R., Michalick, M. S. M., Silva, M. E., Santos, C. C. P., Frézard, F. J. G. \& Silva, S. M. (2018). Canine leishmaniasis: an overview of the current status and strategies for control. Biomed Research International, 2018(6), 1-12.

Santos, R. L. \& Oliveira, A. R. (2019). Leishmaniasis in non-human primates: Clinical and pathological manifestations and potential as reservoirs. Journal of Medical Primatology, 49(1), 34-39.

Saridomichelakis, M. N., Mylonakis, M. E., Leontides, L. S., Koutinas, A. F., Billinis, C. \& Kontos, V. I. (2005). Evaluation of lymph node and bone marrow cytology in the diagnosis of canine leishmaniasis (Leishmania infantum) in symptomatic and asymptomatic dogs. The American Journal of Tropical Medicina and Hygiene, 73(1), 82-86.

Silva, D. A., Madeira, M. F., Abrantes, T. R., Filho, J. L. B. \& Figueiredo, F. B. (2013). Assessment of serological tests for the diagnosis of canine visceral leishmaniasis. Veterinary Journal, 195(2), 252-253. 
Research, Society and Development, v. 10, n. 5, e2310514457, 2021

(CC BY 4.0) | ISSN 2525-3409 | DOI: http://dx.doi.org/10.33448/rsd-v10i5.14457

Silva, D. T., Alves, M. L., Spada, J. C. P., Silveira, R. C. V, Oliveira, T. M. F. S. \& Starke-Buzzeti, W. A. (2018). Neutrophils, eosinophils, and mast cells in the intestinal wall of dogs naturally infected with leishmania infantum. Brazilian Journal of Veterinary Parasitology, 27(4), 430-438.

Silva, J. A. O., Silva, F. J., Macedo, L. O., Santos, C. V. B., Alves, L.C., Ramos, R. A. N., Faustino, M. A. G. \& Carvalho, G. A. C. (2019). Sandflies in an endemic área for visceral leishmaniasis in northeastern brazil. Brazilian Journal of Veterinary Parasitology, 28(4), 569-573.

Teles, N. M. M., Agostini, M. A. P., Bigeli, J. G., Noleto, R.V., Oliveira, J. D. \& Oliveira-Junior, M. P. (2012). Molecular and parasitological detection of Leishmania spp. in dogs caught in Palmas, TO, Brazil. Revista Brasileira de Parasitologia Veterinária ,21(3), 278-282.

Tilley, L. P. \& Smith Jr, F. W. K. (2008). Consulta veterinária em cinco minutos. Espécies canina e felina. Manole.

Torrecilha, R. B. P., Utsunomiya, Y. T., Bosco, A.M., Almeida, B. F., Pereira, P. P., Narciso, L. G., Pereira, D. C. M., Baptistiolli, L., Calvo-Baldo, L. \& Courtnenay, O. (2016). Correlations between peripheral parasite load and common clinical and laboratory alterations in dogs with visceral leishmaniasis. Preventive Veterinary Medicine, 132, 83-87. 